\title{
Understanding reservoir heterogeneity using variography and data analysis: an example from coastal swamp deposits, Niger Delta Basin (Nigeria)
}

\author{
Ifeanyichukwu S. Obi ${ }^{1}$, K. Mosto Onuoha ${ }^{2}$, Olusegun T. Obilaja ${ }^{3}$, \\ C. I. Princeton Dim \\ ${ }^{1}$ Mobil Producing Nigeria Unlimited, Lagos, Nigeria \\ ${ }^{2}$ Department of Geology, University of Nigeria, Nsukka, Enugu State, Nigeria \\ ${ }^{3}$ Shell Petroleum Development Company, Port Harcourt, Nigeria \\ *corresponding author, e-mail: princeton.dim@gmail.com; princeton.dim@unn.edu.ng
}

\begin{abstract}
For efficient reservoir management and long-term field development strategies, most geologists and asset managers pay special attention to reservoir chance of success. To minimise this uncertainty, a good understanding of reservoir presence and adequacy is required for better ranking of infill opportunities and optimal well placement. This can be quite challenging due to insufficient data and complexities that are typically associated with areas with compounded tectonostratigraphic framework. For the present paper, data analysis and variography were used firstly to examine possible geological factors that determine directions in which reservoirs show minimum heterogeneity for both discrete and continuous properties; secondly, to determine the maximum range and degree of variability of key reservoir petrophysical properties from the variogram, and thirdly, to highlight possible geological controls on reservoir distribution trends as well as areas with optimal reservoir quality. Discrete properties evaluated were lithology and genetic units, while continuous properties examined were porosity and net-to-gross $(\mathrm{NtG})$. From the variogram analysis, the sandy lithology shows minimum heterogeneity in east-west (E-W) and north-south (N-S) directions, for Upper Shoreface Sands (USF) and Fluvial/Tidal Channel Sands (FCX/TCS), respectively. Porosity and NtG both show the least heterogeneity in the E-W axis for reservoirs belonging to both Upper Shoreface and Fluvial Channel environments with porosity showing a slightly higher range than NtG. The vertical ranges for both continuous properties did not show a clear trend. The Sequential Indicator Simulation (SIS) and Object modelling algorithm were used for modelling the discrete properties, while Sequential Gaussian Simulation (SGS) was used for modelling of the continuous properties. Results from this exercise show that depositional environment, sediment provenance, topographical slope, sub-regional structural trends, shoreline orientation and longshore currents, could have significant impacts on reservoir spatial distribution and property trends. This understanding could be applied in reservoir prediction and for generating stochastic estimates of petrophysical properties for nearby exploration assets of similar depositional environments.
\end{abstract}

Key words: Porosity, permeability, flow zone index, property modelling, shoreface, fluvial channels 


\section{Introduction}

The examination of potential factors that control the spatial distribution and property of reservoirs is one approach to successful prediction of key petrophysical properties away from existing well locations. Geostatistical tools are commonly used for the evaluation and prediction of parameters away from control locations, either by using simple linear estimators (ordinary kriging) or by stochastic simulation (Soltani et al., 2013). The ordinary kriging method is often locally inaccurate in the minimum error variance and spatial variabilities generated. It uses the moving average which does not capture small-scale variations in attributes due to smoothening effects and is usually referred to as the "best linear unbiased estimator" (Leuangthong et al., 2004). For the present work, discrete properties were modelled using Object Modelling because this allows for population of discrete facies model with objects which are generated and distributed stochastically. In this case, geometrical inputs controlling the body shape (width/thickness, etc.) can either be defined deterministically, follow a defined statistical distribution or be assigned using a trend map.

A more reliable approach is the use of geostatistical techniques called the sequential simulation. This has become the preferred technology for simulations, because it uses information from histograms and variogram(s) generated from the control data (Gomez-Hernandez \& Journel, 1993). According to Delbari et al. (2009), spatial uncertainties at both sampled and unsampled locations are taken into account by the geostatistical sequential simulation algorithms, hence its use to assess local and spatial uncertainties (Deutsch \& Journel, 1998).

In the present study, which was carried out in one of the onshore fields of the Niger Delta Basin, a detailed data analysis was carried out on selected reservoirs in order to evaluate variations in sands and genetic unit distribution, and also examine spatial variations in porosity and net-to-gross. Our focus intervals are Lower Miocene reservoirs located in the eastern part of the Coastal Swamp Cenozoic Depobelt of the Niger Delta Basin (Fig. 1A-C). Previous work here was documented by Obi \& Onuoha (2017) and Obi et al. (2017). The area is underlain by basal marine shales (Akata Formation), coastal plain sand-shale alternations (Agbada Formation) and coastal plain sands (Benin Formation) as the youngest stratigraphical unit at the shallower part of the basin (Fig. 1D).

\section{Geological setting}

Tectonic frameworks along the west coast of equatorial Africa are linked to the palaeo-Niger and Benue system and controlled by Cretaceous fracture zones which occur as trenches and ridges in the deep Atlantic (Doust \& Omatsola, 1990). The fracture zone subdivides the continental margin into individual basins, and, in Nigeria, forms the boundary faults of the Cretaceous Benue-Abakaliki Trough, which cuts far into the West African shield. The trough represents a failed arm of a rift triple junction associated with the opening of the South Atlantic. In this region, rifting started during the Late Jurassic and persisted into the mid-Cretaceous (Lehner \& De Ruiter, 1977) and up to the Late Cretaceous when it ceased. Gravity tectonics became the primary deformational process. The basal mobile rocks triggered internal deformation in response to two processes. Firstly, discordant mud structures formed from loading of poorly compacted, over-pressured, prodelta and delta-slope mudrocks (Akata Formation) by the higher density delta-front sands (Agbada Formation). The second stage featured slope instability triggered by a lack of lateral, basinward support for the under-compacted delta-slope mud rocks. These faults mostly offset different parts of the Agbada Formation and flattened into detachment planes near the top of the Akata Formation. For any given depobelt, gravity tectonics were completed before deposition of the Benin Formation and are expressed in complex structures, including mobile substrates, roll-over anticlines, collapsed crestal faults and steeply dipping keystone faults (Evamy et al., 1978).

In terms of stratigraphical framework, Cenozoic deposits in this basin are comprised of thick, complex sedimentary units deposited rapidly during high-frequency, fluvio-deltaic-eustatic sea level oscillations. The surface upon which they were deposited is underlain by thick, under-compacted unstable mobile shales (Mitchum et al., 1994). The Cenozoic Niger Delta is divided into three formations, representing prograding depositional facies that are distinguished mostly on the basis of sandshale ratios. The Akata Formation at the base of the delta is of marine origin and is composed of thick shale sequences (potential source rock), turbidite sands (potential reservoirs in deep water) and minor amounts of clay and silt.

Beginning in the Paleocene, the Akata Formation formed during a lowstand when terrestrial organic matter and clays were transported to deep-water areas characterised by low-energy conditions and oxygen deficiency (Stacher, 1995). The 

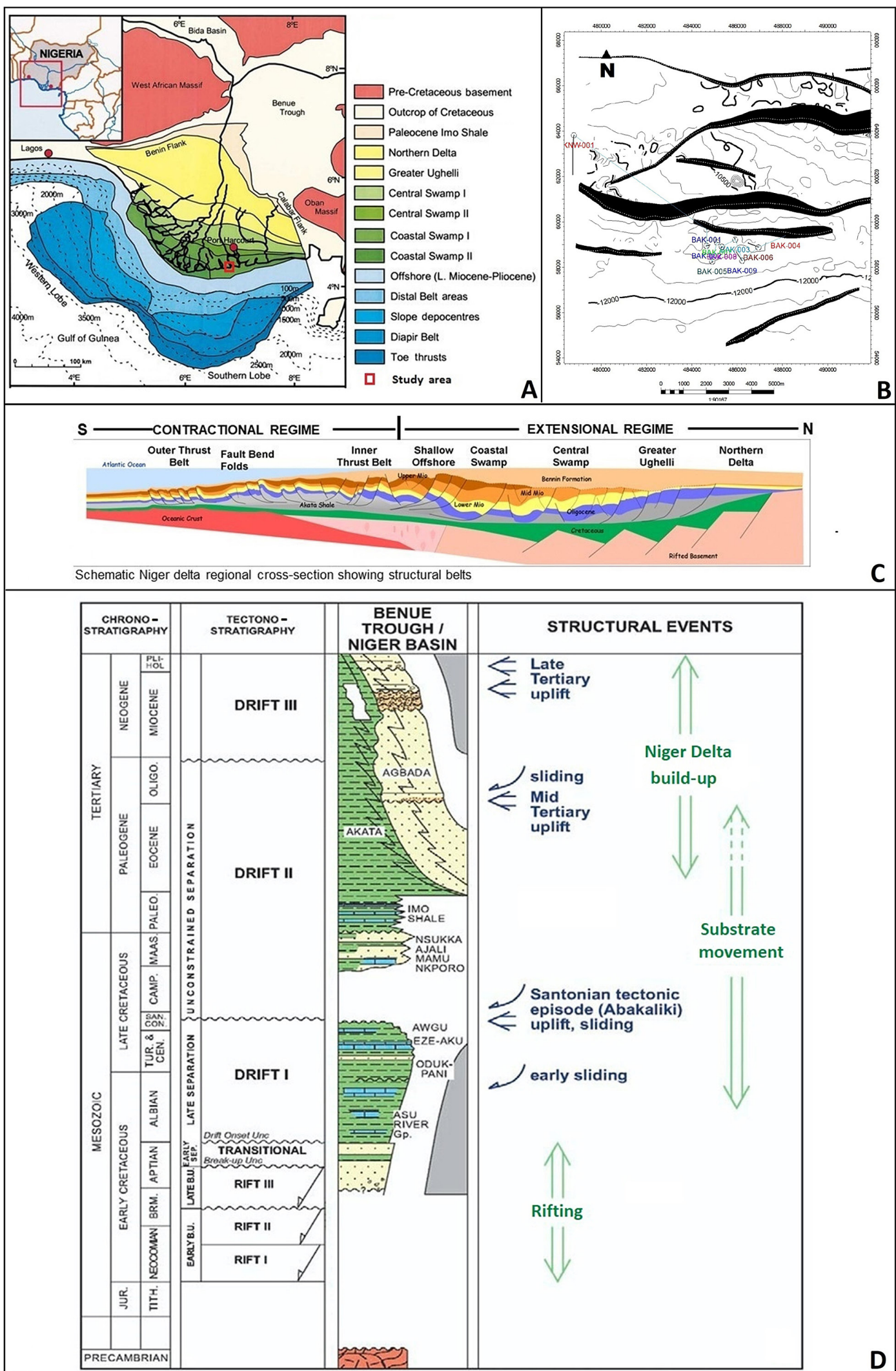

Fig. 1. A - Map of southern Nigeria showing the depositional belts of the Niger Delta Basin and the study area within the coastal swamp depobelt (after Hooper et al., 2002); B - Map of the study area showing well locations and major faults; C - Schematic Niger Delta regional dip-section showing structural belts (after Hooper et al., 2002); D -Tectonostratigraphy of the Niger Delta Basin showing major phases of evolution (modified from Lawrence et al., 2002) 
formation underlies the entire delta and is typically over pressured. The Akata formation is overlain by the Eocene to Recent Agbada Formation. This petroleum-bearing unit of the delta consists of a paralic siliciclastic of over 3,700 metres in thickness, representing the actual deltaic portion of the deltaic sequence. Some authors prefer to split the Agbada Formation into a lower and upper portion. In the lower Agbada Formation, shale and sandstone beds were deposited in equal proportions; however, the upper portion is mostly sand with minor shale interbeds. The Agbada Formation is overlain by the third unit, the Benin Formation, a continental uppermost Eocene to Recent deposit of alluvial and upper coastal plain sands.

\section{Data set and methodology}

\subsection{Framework and reservoir property definition}

Framework horizon and fault interpretations were done on Pre-Stack Time Migrated (PSTM) seismic data, as well as some derivative volumes such as seismic discontinuity and frequency attributes. Rock properties such as porosity and permeability, and fluid type or properties such as saturation, were determined using available geophysical log suites, well production data, reservoir petrophysical reports and core information. One common pitfall of Petrel-estimated porosity and permeability is the resolution constraint and other cumulative errors from tool settings. This is especially because the output porosity log, for example, is only as good as the sampling rate of the parent wireline log. Also, permeability estimation in petrel can be quite tricky as the tool uses an in-built empirical poro-perm transform for these two parameters. With this limitation in mind, best practices typically entail integration of the predicted poro-perm values with log interpretations and sometimes laboratory measurements from well cores. To minimise these errors for this project, besides integrating core-log data, we used interactive syntaxes containing porosity and v-shale as key inputs to define cut-offs for designating lithology and genetic units. This was an iterative process as cut-offs were determined interactively by comparing outputs with actual core data. The approach was to vary the syntax parameters until its prediction matches with core measurements of sand, silt or shale from cores. Lithology in this context refers to rock type (sand, silt or shale), while reservoir genetic units refer to stratigraphical packages that were deposited within a sedimentary environment under unique depositional conditions such that each genetic unit has a distinct hydraulic flow behaviour. Lithologies or rock types were identified using the combination of gamma ray (GR) log, petrel calculator and sidewall core reports. The Petrel calculator integrates porosity (POR), permeability (PERM) and net-to-gross (from $\mathrm{V}$-shale or gamma ray log readings). The syntax used is given by 'Lithology$=$ If $(\text { POR }<0.13 \text {, 0, If }(\text { POR<0.2, 2, If }(N t G<0.2,0,1)))^{\prime}$. Wells with porosity log missing at certain intervals had unsatisfactory lithological logs especially at depths with poor GR or porosity readings. For such wells, the facies were re-defined using the syntax: Lithology $=I f(P O R<0.13,0, \operatorname{If}(P O R<0.2,2$, If $(N t G<0.2$, 0, If( PERM<0.01, 0, 1)))).

The individual genetic units were defined by integration of geophysical log signatures, core interpretation and flow zone index (FZI). The FZI is a quantitative petrophysical tool (equation 1) used to classify reservoirs into distinct units based on their hydraulic flow properties (Uguru et al., 2005; Obi \& Onuoha, 2017). Its equation was originally introduced by Amaefule et al. (1993) and involved Normal Porosity Index (NPI) and Reservoir Quality Index (RQI) (equation 1). A modified version of this relationship relating porosity, permeability and flow zone index (equation 2) was provided for coastal swamp deposits of the Cenozoic Niger Delta Basin by Uguru et al. (2005). The FZI for porous and permeable layers from a well are calculated from transformation of gamma ray, neutron porosity, density and deep resistivity logs (Tanmay, 2008). The reservoirs evaluated were classified into three distinct genetic units (or facies) namely Upper Shoreface (USF), Fluvial Channels (FCX) and Tidal Channel (TCS) deposits.

$$
\mathrm{FZI}=\mathrm{RQI} / \mathrm{NPI}=\{(0.0314 \sqrt{ } \mathrm{K} / \Phi)\} /\{\Phi /(1-\Phi)\}
$$

(Amaefule et al., 1993; Al Dhafeeri et al., 2007)

$\left.\mathrm{K}=1014\left\{(\mathrm{FZI})^{2} \Phi^{3}\right) /(1-\Phi)^{2}\right\}$ (Uguru et al., 2005) (2)

where: FZI - Flow Zone Indicator $[\mu \mathrm{m}]$; K - Permeability [md]; NPI - Normal Porosity Index; RQI Reservoir Quality Index.

The next step was the upscaling of both discrete and continuous reservoir properties followed by data and variogram analyses for the upscaled properties. A variogram is a mathematical function that describes the natural "variation" present in the data in a specific direction (Zakari et al., 2016). Variogram plots provide information on the directions of maximum range (i.e., minimum heterogeneity) for the lithology, genetic units, porosity, permeability and net-to-gross in any field. 


\subsection{Variogram analysis and property modelling}

Part of the exercise during this reservoir property analysis included the creation of variograms. Variograms show different types of shape depending of the nature and scale of variability for the property in question. These shapes may show trends which are either repeated, oscillating or, in some cases, irregular. Parameters evaluated in this exercise include the range, sill, variogram shapes and nugget. However, for the present paper, the primary focus was on the range statistics, especially in different direction per lithology and genetic units. It should be noted that the gross depositional environments for the reservoirs would have been defined by this stage (core, well log and RQI integration). With this in mind, one would expect measurable contrast in heterogeneity for reservoirs of different genetic origin. For example, if we consider fluvial vs shoreface sands, the latter are likely to show more continuity (i.e., higher ranges) in a W-E direction, mostly mimicking the palaeo-shoreline trend, while the fluvial complexes are more likely to show more continuity in varied trends depending on the prevalent downstream flow direction. Palaeo-slopes and basin tectonics have been known to impact depositional trends. The ranges were obtained by reading off these parameters from the Petrel-generated individ- ual variograms (Fig. 4) showing reservoir properties in N-S (major), W-E (minor) and vertical directions paths, generated per lithofacies or genetic units. Tables 1 and 2 show the record of some ranges, as well as the reservoir sill and nugget. The range refers to the maximum distance within which data can be correlated in a particular direction (Cabrera-Garzon et al., 1997). For example, if $\mathrm{A}$ is the range for a variable in a particular direction, a data point at location $\mathrm{X}$ can be correlated to a maximum distance of $\mathrm{A}$ from that location. Beyond the range, the two points bear no relation to each other. Thus, large range means greater continuity (major direction path), while small range means less continuity (minor direction path). The larger the range, the smaller the heterogeneity. In other words, larger range means a higher probability of obtaining the same value or property at greater distances from the sample point. A smaller range implies more erratic behaviours in the parameter over a small distance. Typically, range is estimated in three directions namely, major, minor and vertical directions paths.

\subsection{Discrete property modelling}

Modelling of lithologies and genetic units was carried out using the Object Modelling algorithm (which allows to populate a discrete property mod-

Fig. 2. 3D-framework skeleton showing modelled horizons and faults

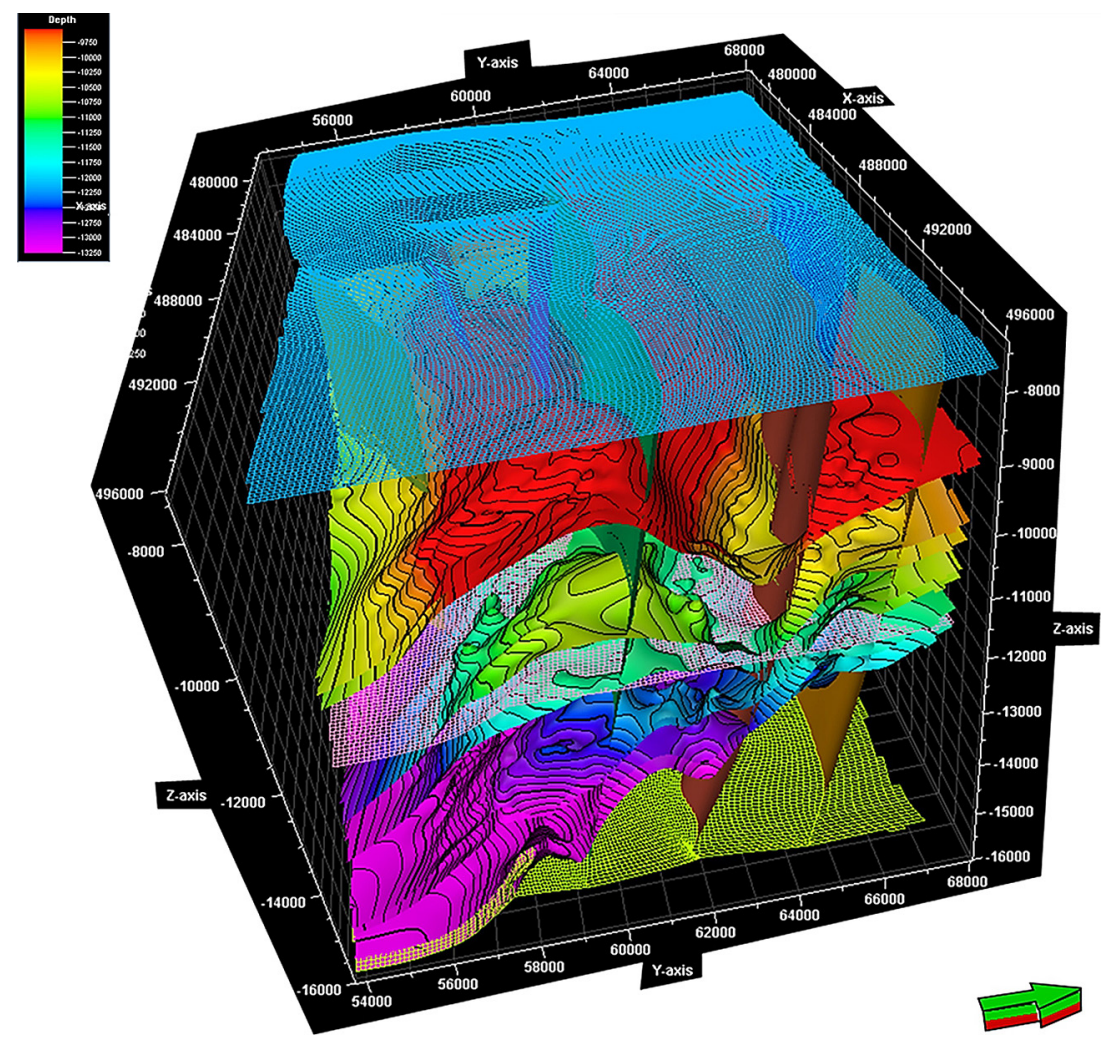


el with objects which are generated and distributed stochastically) and the Sequential indicator simulation (SIS) (most appropriate for use where either the shape of particular facies bodies is uncertain or where there are a number of trends which could control the facies type). With SIS, the result is dependent upon upscaled well log data, defined variogram, random seed, frequency distribution of upscaled data points, or trends in 1-D, 2-D or 3-D. The three-dimensional estimation of properties, for example, porosity, requires knowledge of both the probability distribution and the co-variance or variogram model (Deutsch \& Journel, 1998). For the present project, we carried out data analysis for evaluation of key parameters such as probability charts, thickness and variogram curves.

\subsection{Continuous property modelling}

Two continuous properties modelled in the present study are Porosity and Net-to-Gross. The exercise includes the simulation or interpolation of continuous properties as opposed to discrete properties such as facies type (where the 'value' is either sand or shale represented by integers). For the present work, the Sequential Gaussian Simulation (SGS) algorithm was used in building the porosity and net-to-gross model. This approach uses stochastic random values conditioned from available field input to model and assess spatial uncertainty in reservoir property or other geological attributes (Dimitrakopoulos \& Luo, 2004). The SGS algorithm honours well data, input distributions, variograms and trends. The variogram and distribution are used to create local variations, even away from input data. Other exercises, which formed part of the building process for the framework skeleton, included pillar gridding, zoning and layering (Fig. 2). Reservoir zones were divided into smaller layers with a vertical resolution of $10 \mathrm{ft}$ for each zone. Figure 3 shows a section of the modelled NtG for the B3 reservoir. The ranges obtained for the N-S (major range), E-W (minor range) and $\mathrm{Z}$ (vertical range) directions for each property are documented in Tables 1 and 2. Details of other information such as variogram shape, zones and facies settings, and key transformations carried out, especially for porosity and net-to-gross, are shown in Figures $4 \mathrm{~A}$ and $4 \mathrm{~B}$, respectively.

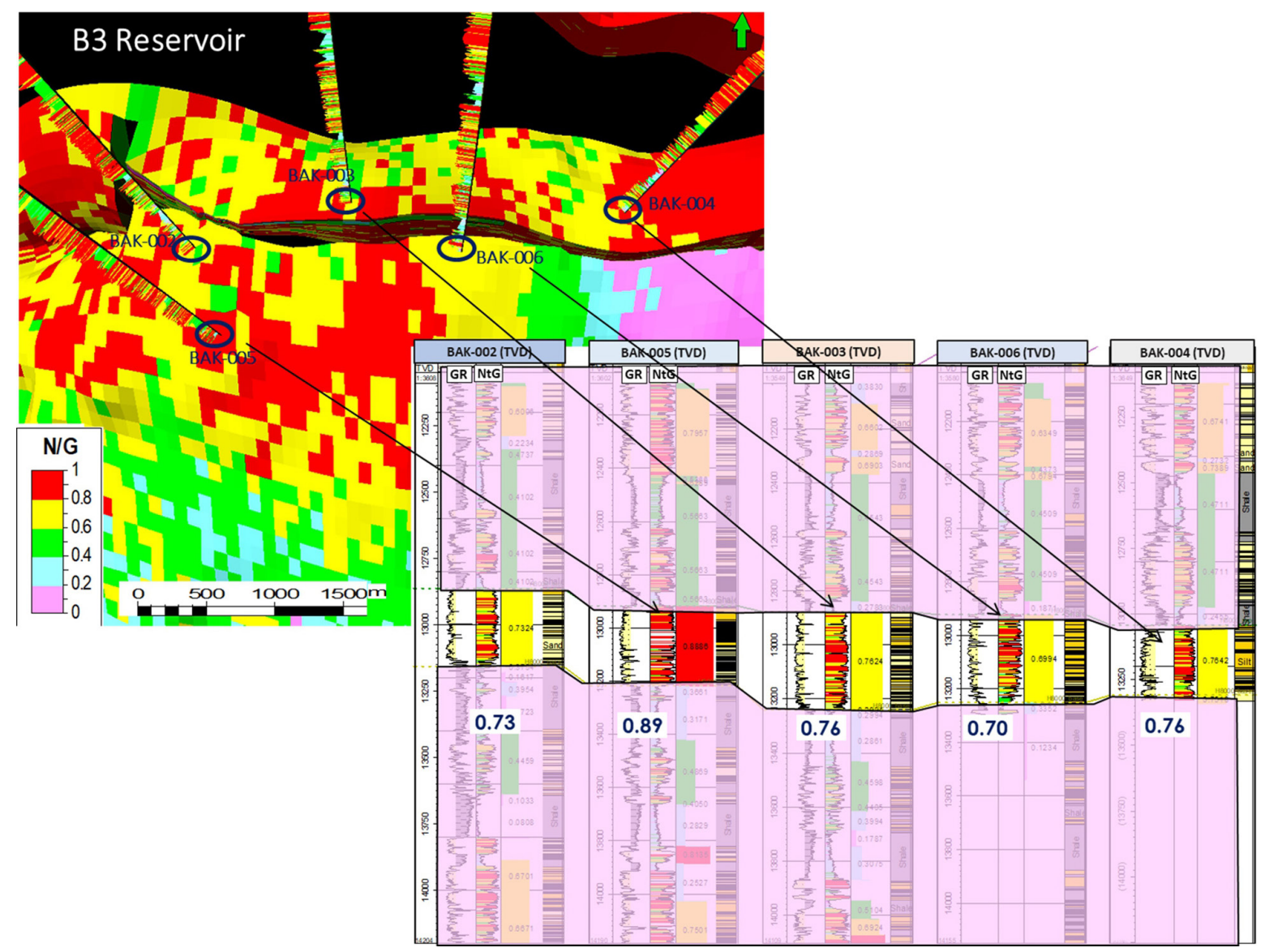

Fig. 3. 3D- and well-section window showing modelled $\mathrm{NtG}$ for the B3 reservoir 


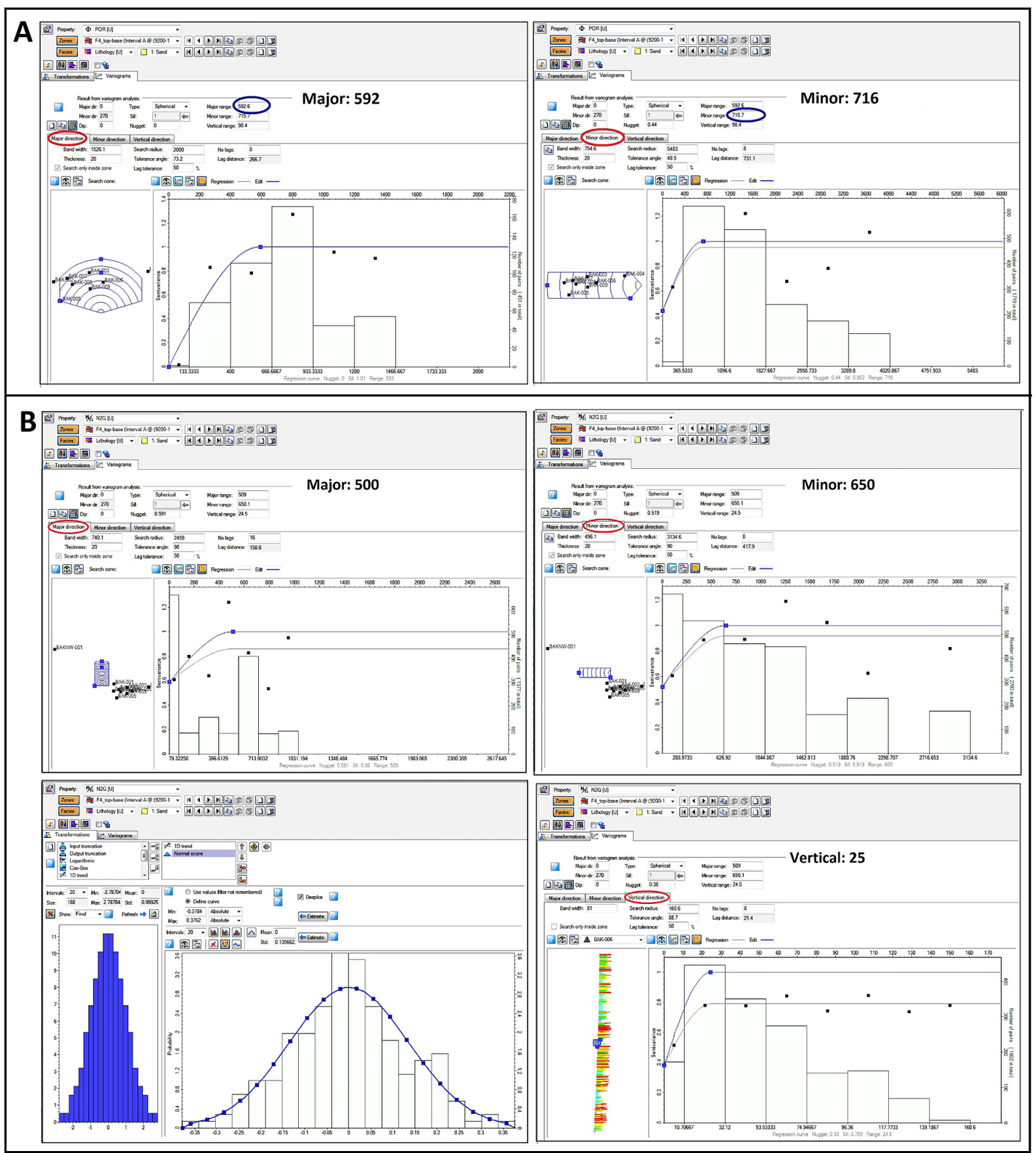

Fig. 4. A - B1 reservoir porosity data analysis showing variogram shape and ranges; B - B1 reservoir NTG data analysis showing variogram shape and ranges

\section{Results and discussion}

\subsection{Lithology and genetic units}

Some notes are here added on the geology of the individual reservoirs within the context of depositional sequences. The B1 reservoir is dominated by fluvial complexes deposited as late highstand and early lowstand packages in a coastal delta- ic setting (10.6-10.4 Ma). The B2 sands are mostly well developed, late highstand shoreface deposits of inner to mid-shelf settings (11.5-10.6 Ma). They are occasionally blocky on GR logs with generally high interval NtG. The B3 reservoirs contain mostly lower shoreface deposits of early highstand origin deposited in inner to mid-shelf environments (11.510.6 Ma). They are generally heterolithic with an appreciable non-net content. The B4 reservoirs con- 
Table 1. Summary of data analysis for sand facies of different genetic units

\begin{tabular}{|c|c|c|c|c|c|}
\hline Reservoir & Genetic unit & Axis/Parameter & Nugget & Sill & Range \\
\hline \multirow[t]{6}{*}{ B1 } & \multirow[t]{3}{*}{ Upper Shoreface (USF) } & N-S major direction & 0 & 1.03 & 653 \\
\hline & & $\mathrm{E}-\mathrm{W}$ minor direction & 0.25 & 0.29 & 3308 \\
\hline & & Z vertical direction & 0 & 0.49 & 23 \\
\hline & \multirow[t]{3}{*}{ Fluvial Channel (FCX) } & N-S major direction & 0.5 & 1.5 & 3397 \\
\hline & & E-W minor direction & 0.3 & 1.1 & 415 \\
\hline & & Z vertical direction & 0.5 & 1.16 & 46 \\
\hline \multirow[t]{6}{*}{ B2 } & \multirow[t]{3}{*}{ Upper Shoreface (USF) } & N-S major direction & 0.5 & 1.21 & 159 \\
\hline & & E-W minor direction & 0.7 & 2.2 & 3240 \\
\hline & & $\mathrm{Z}$ vertical direction & 0.7 & 0.7 & 46 \\
\hline & \multirow[t]{3}{*}{ Fluvial Channel (FCX) } & N-S major direction & 0.5 & 1.3 & 1408 \\
\hline & & E-W minor direction & 0.5 & 1.1 & 776 \\
\hline & & Z vertical direction & 0.4 & 0.8 & 23 \\
\hline \multirow[t]{6}{*}{ B3 } & \multirow[t]{3}{*}{ Upper Shoreface (USF) } & N-S major direction & 0.6 & 1 & 447 \\
\hline & & E-W minor direction & 0.7 & 0.99 & 1900 \\
\hline & & $\mathrm{Z}$ vertical direction & 0.57 & 0.92 & 22 \\
\hline & \multirow[t]{3}{*}{ Fluvial Channel (FCX) } & N-S major direction & 0.35 & 1.3 & 728 \\
\hline & & E-W minor direction & 0.4 & 0.87 & 544 \\
\hline & & Z vertical direction & 0.28 & 0.88 & 99 \\
\hline \multirow[t]{6}{*}{ B4 } & \multirow[t]{3}{*}{ Upper Shoreface (USF) } & N-S major direction & 0.23 & 1.03 & 349 \\
\hline & & E-W minor direction & 0.28 & 1.1 & 796 \\
\hline & & Z vertical direction & 0 & 1.3 & 62 \\
\hline & \multirow[t]{3}{*}{ Fluvial Channel (FCX) } & N-S major direction & 0 & 1.8 & 1161 \\
\hline & & $\mathrm{E}-\mathrm{W}$ minor direction & 0 & 1.5 & 1582 \\
\hline & & $\mathrm{Z}$ vertical direction & NA & NA & NA \\
\hline
\end{tabular}
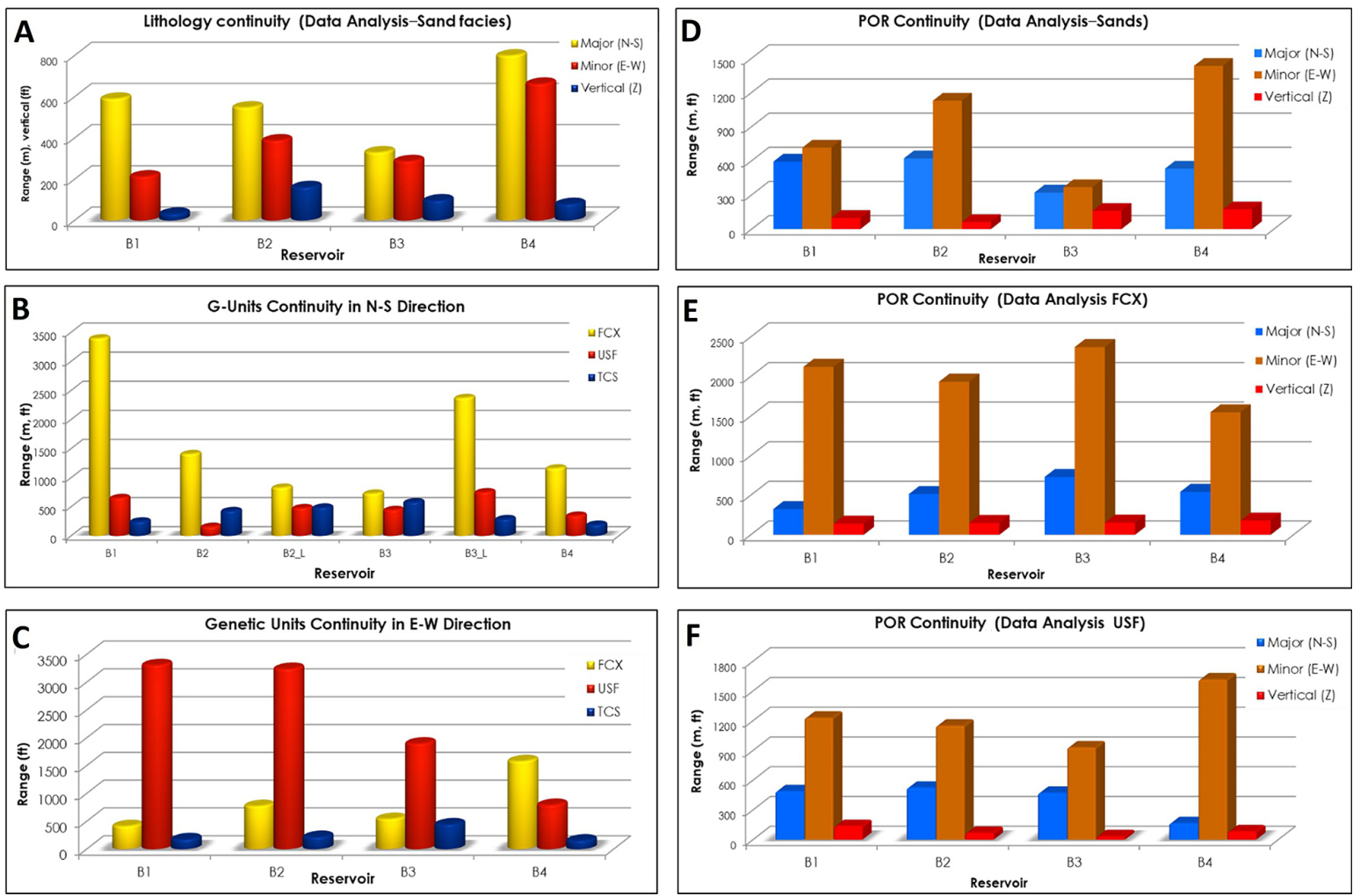

Fig. 5. A - Sand facies range for B1, B2, B3 and B4 reservoirs in N-S, E-W and vertical directions; B - N-S range for upper shoreface (USF), fluvial channel complex (FCX) and tidal channel sands (TCS); C - E-W range for upper shoreface (USF), fluvial channel complex (FCX) and tidal channel sands (TCS); D - Porosity ranges in N-S, E-W and $\mathrm{Z}$ directions for sand facies in B1, B2, B3 and B4 reservoirs (no genetic unit constraint); E - Porosity ranges in N-S, $\mathrm{E}-\mathrm{W}$ and $\mathrm{Z}$ directions for fluvial channel complexes (FCX) in B1, B2, B3 and B4 reservoirs; F - Porosity ranges in N-S, E-W and Z directions for upper shoreface sands (USF) in B1, B2, B3 and B4 reservoirs 
tain predominantly high-quality upper shoreface sands within a highstand system tracts deposited in shelf-margin conditions (pre-11.5 Ma).

Variogram analysis shows that sands in this area are more continuous in a N-S direction if unconstrained to any specific genetic unit (Fig. 5A). However, when constrained to distinct different genetic units, the direction least reservoir heterogeneity varies (Table 1). For example, reservoirs of fluvial channel origin recorded maximum ranges between $0.5-3.5 \mathrm{~km}$ in a N-S direction for all six reservoirs analysed (Fig. 5B; Table 1), the shoreface intervals recorded longer ranges in the E-W axis (Fig. 5C; Table 1), while the tidal channel sands did not show any clear direction of preferred reservoir continuity. The maximum ranges for upper shoreface and tidal channel facies are 3.2 and $0.6 \mathrm{~km}$, respectively. It is interpreted that the fluvial sands show more continuity (i.e., less entropy) in the N-S axis, being predominantly controlled by sediment provenance (approximately N-S in this part of the basin) as well as slope. Typically, depositional trends for fluvial environments determine the overall orientation of the reservoirs. For example, mud-filled systems trending fairly N-S in part explains the observations in Figure 5B. On the other hand, reservoirs of shallow-marine origin (for example, upper shoreface settings) with prograding or retrograding shoreline movements, show better quality and continuity in the E-W axis, suggesting regional shoreline orientation or longshore currents (Fig. 5C) as key controlling factors. The Tidal Channel Sands (TCS), with the smallest range in both N-S and E-W axis, are interpreted to have formed in localised tidal channels (Fig. 5B, C).

\subsection{Porosity and Net-to-Gross}

Reservoir porosity is primarily driven by depth of burial and compaction trend. However, the cleaner the reservoir (net-to-gross ratio), the higher the average porosity. According to Obi et al. (2017), the relationship between average porosity and reservoir net-to-gross is better defined when considered for reservoirs of the same gross depositional environment or flow properties. It was further hinted at that reservoirs with less heterogeneity in a particular direction will show greater continuity in its average porosity in that direction. For this exercise, the evaluated porosity and NtG showed maximum ranges in the E-W axis for this area (Fig. 5D-F; Table 2). The plots show that the maximum ranges in the E-W direction are the same for both fluvial channels and upper shoreface, and even the same where the reservoirs are not constrained to any genetic unit type or depositional environment. For example, when the porosity is unconstrained to any environment of deposition, the maximum ranges in an E-W direction are between 300 and 1,350 m (Fig. 5D). Similarly, Figures 5E and 5F also show that porosity had maximum ranges in an $\mathrm{E}-\mathrm{W}$ direction for reservoirs of fluvial and shoreface origin.

Similar to earlier observations in the data analysis for porosity, the reservoir NtG show minimum heterogeneity in an E-W direction, and hence maximum ranges (Table 2). In the case where the reservoirs were not pre-defined based on genetic unit, the maximum range recorded was about $1,300 \mathrm{~m}$. For reservoirs of distinct genetic origin, the analysis shows that the fluvial channel complexes showed ranges up to $2 \mathrm{~km}$, while the shoreface reservoirs

Table 2. Summary of Net-to-Gross range for upper shoreface and channel sands

\begin{tabular}{lcccc}
\hline & Reservoir & Major (N-S) & Minor (E-W) & Vertical (Z) \\
\hline NtG Range & B1 & 283 & 527 & 15 \\
Upper Shoreface (USF) & B2 & 533 & 963 & 17 \\
& B3 & 584 & 710 & 32 \\
\hline NtG Range & B4 & 489 & 647 & 45 \\
Fluvial Channel (FCX) & B1 & 267 & 1326 & 23 \\
& B2 & 1032 & 1360 & 98 \\
Porosity Range & B3 & 720 & 2084 & 28 \\
Upper Shoreface (USF) & B4 & 664 & 1298 & 137 \\
& B2 & 488 & 1229 & 67 \\
Porosity Range & B3 & 523 & 1149 & 32 \\
Fluvial Channel (FCX) & B4 & 471 & 930 & 83 \\
& B1 & 166 & 1615 & 141 \\
\hline
\end{tabular}


recorded a maximum range of $900 \mathrm{~m}$. Although the driving mechanism of these ranges is not clear for both porosity and net-to-gross, it is interpreted that the preferential homogeneity in an $\mathrm{E}-\mathrm{W}$ direction is impacted either by longshore currents or by the hydrodynamics of the depositional medium (Obi
\& Mode, 2011). It is interpreted that longshore currents generated during high-energy waves in this part of the basin would spread deposits preferentially over an E-W axis.

Syn- or post-depositional structures can also play an important role in the overall trend of reservoirs
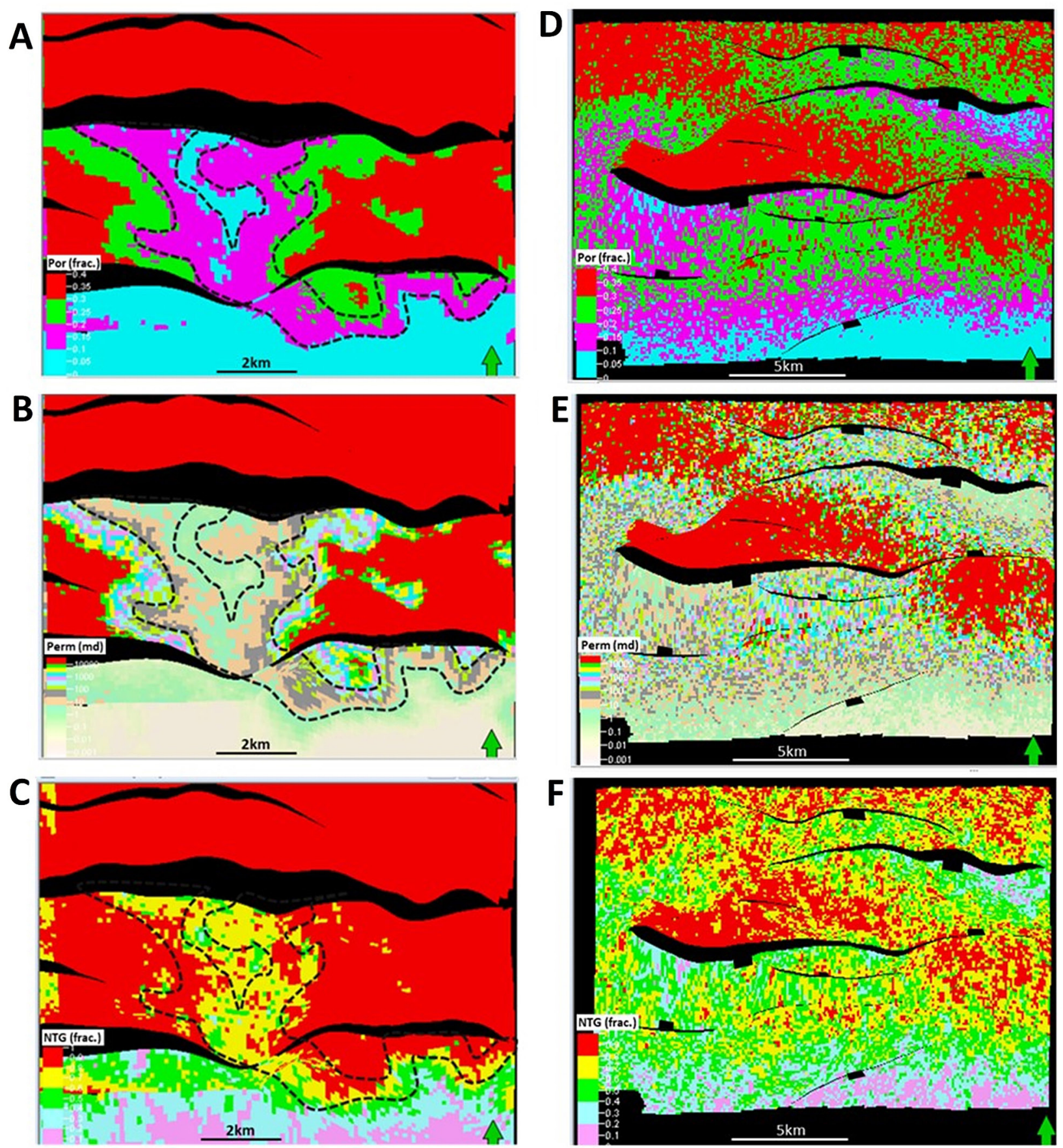

Fig. 6. A - Top structural map showing low porosity in dashed black lines; B - Top structural map showing low permeability zones in dashed black lines; C - Top structural map showing low NtG zones in dashed black lines. This is an example to illustrate where observed changes in the fairway trend were likely impacted by pre- or syn-depositional structures within the basin; D - Reservoir zone showing porosity property trend; E - Reservoir zone showing permeability trend; F - Reservoir zone showing NtG property trend. Note areas around the fault that show better reservoir properties 
as well as in the maximum ranges recorded. Figures 6A-F show examples where reservoir distribution and average properties were impacted by structural and depositional features, respectively. We opine that, at smaller scales, diagenesis could have direct impact on reservoir property distribution and three-dimensional heterogeneity. For example, although the present work does not have any derived empirical relationship demonstrating this, the static model for a sample zone (Fig. 6D-F), shows some degree of qualitative correlation between $\mathrm{NtG}$ and porosity and permeability.

\section{Conclusions}

The direction in which reservoirs record minimum heterogeneity (or maximum range) was systematically examined using data analysis and variography for selected discrete and continuous reservoir properties. In the present project, it is shown in the variogram and data analysis that presence of sand, when unconstrained to distinct genetic units or depositional environments, shows less heterogeneity in a north-south direction. On the other hand, when constrained to specific environments of deposition, reservoirs of fluvial and upper shoreface origin show the least heterogeneity along the north-south and east-west axis, respectively. In all, sediment provenance and palaeoslope were interpreted as key controls on sand distribution trends for the fluvial channel sands, while longshore currents and shoreline orientation are interpreted to have a major influence on the reservoir distribution in upper shoreface environments. From this exercise, it is observed that irrespective of genetic depositional environment, pre- or syn-depositional tectonic structures could have significant controls on reservoir distribution in this area. For the continuous properties, the present study shows that reservoir properties such as netto-gross and average porosity show more continuity along an east-west axis, whether constrained to any genetic depositional unit or not. Although the cause of this is unclear, the east-west trend in the properties of shoreface reservoirs is interpreted to be impacted by the effect of winnowing by longshore currents. It is also suggested that diagenesis might also impact reservoir petrophysical properties and 3D-spatial heterogeneities. Overall, average porosity has slightly larger maximum ranges than netto-gross. Data obtained in the present project were applied in successfully predicting the spatial distribution of porosity and net-to-gross, as well as generating stochastic volume estimates for two nearby fields within this depobelt of the basin. In addition to making better well-placement decisions, knowledge gained from our data analysis of reservoirs can be applied to predict reservoir properties away from well controls. Stochastic estimates for porosity and net-to-gross values can also be generated for use in quick-look volume estimation in frontier locations.

\section{Acknowledgements}

We are grateful the Shell Petroleum Development Company of Nigeria, who sponsored this work which formed part of the PhD thesis of the senior author, and to Mr Otuka Umahi (Shell Nigeria) for his contributions and guidance in the modelling part of the project.

\section{References}

Al-Dhafeeri, A.M. \& Nasr-El-Din, H.A., 2007. Characteristics of high permeability zones using core analysis and production logging data. Journal of Petroleum Science and Engineering 55, 13-25.

Amaefule, J.O., Altunbay, M., Tiab, D., Kersey, D.G. \& Keelan, D.K., 1993. Enhanced Reservoir Description: Using core and log data to identify hydraulic (flow) units and predict permeability in uncored intervals/wells. $68^{\text {th }} \mathrm{SPE}$ Annual Technical Conference and Exhibition, Houston, USA. Paper SPE-26436, 16 pp.

Cabrera-Garzon, R., Arestad, J.F., Dagdelen, K. \& Davis, T.L., 1997. Geostatistical simulation of reservoir porosity distribution from 3-D, 3-C seismic reflection and core data in the Lower Nisku Formarion at Joffre Field, Alberta. [in:] J.A. Kupez, J. Gluyas \& S. Bloch (Eds), Reservoir quality prediction in sandstones and carbonates. American Association of Petroleum Geologists Memoir 60, 115-125.

Delbari, M., Afrasiab, P. \& Loiskandl, W., 2009. Using sequential Gaussian simulation to assess the field-scale spatial uncertainty of soil water content. Catena 79, 163-169.

Deutsch, C. \& Journel, A.G., 1998. GSLIB: Geostatistical Software Library and User's Guide. $2^{\text {nd }}$ edition. Oxford University Press, 340 pp.

Dimitrakopoulos R., \& Luo, X., 2004. Generalized sequential Gaussian simulation on group size $\mathrm{v}$ and screen-effect approximations for large field simulations. Mathematical Geology 36, 567-591.

Doust, H., \& Omatsola, E., 1990. Niger Delta [In:] J.D. Edwards \& P.A. Santogrossi (Eds): Divergent/passive margin basins. American Association of Petroleum Geologists Memoir 48, 239-248.

Evamy, B.D., Haremboure, J., Kamerling, P., Knaap, W.A., Molloy, F.A. \& Rowlands, P.H., 1978. Hydrocarbon habitat of Tertiary Niger Delta. American Association of Petroleum Geologists Bulletin 62, 277-298.

Gomez-Hernandez, J.J. \& Journel, A.G., 1993. Joint sequential simulation of multigaussian fields. [In:] A. 
Soares (Ed.): Geostatistics Troia '92, Kluwer Academic Publ., 85-94.

Hooper, R.J., Fitzsimmons, R.J., Grant, N. \& Vendeville, B.C., 2002. The role of deformation in controlling depositional patterns in the south-central Niger Delta, West Africa. Journal of Structural Geology 24, 847-859.

Lawrence, S.R., Munday, S. \& Bray, R., 2002. Regional geology and geophysics of the eastern Gulf of Guinea (Niger Delta to Rio Muni). The Leading Edge 21, 11121117.

Lehner, P., \& De Ruiter, P.A.C., 1977. Structural history of Atlantic Margin of Africa. American Association of Petroleum Geologists Bulletin 61, 961-981.

Leuangthong, O., McLennan, J.A, \& Deutsch, C.V., 2004. Minimum acceptance criteria for geostatistical realizations. Natural Resources Research 13, 131-141.

Mitchum, R.M., Sangree, J.B., Vail, P.R. \& Wornardt, W.W., 1994. Recognizing sequences and systems tracts from well logs, seismic data and biostratigraphy: Examples from the Late Cenozoic of the Gulf of Mexico. American Association of Petroleum Geologists Memoir 58, 163-197.

Obi. I.S. \& Mode, A.W., 2011. Geologic controls on reservoir architecture and heterogeneity: Example from braided river deposits in SE Nigeria. Nigerian Association of Petroleum Explorationists Bulletin 23, 72-87.

Obi, I.S. \& Onuoha, K.M., 2017. Lithology and reservoir facies identification using data integration: An example from the 'Cissero' Field, Onshore Niger Delta Basin. [In:] K.M. Onuoha (Ed.): Advances in Petroleum Geosciences Research in Nigeria - Basin Analysis and Res- ervoir Characterization Studies. Utopia Publishing, Lagos, 33-45.

Obi, I.S., Onuoha, K.M., \& Obilaja, O.T., 2017. Prediction of reservoir properties using Crossplot Trends: An example from Coastal Swamp Depobelt of the Niger Delta Basin, Nigeria. [In:] K.M. Onuoha (Ed.): Advances in Petroleum Geosciences Research in Nigeria - Basin Analysis and Reservoir Characterization Studies. Utopia Publishing, Lagos, 20-32.

Soltani, F., Afzal, P. \& Asghari, O., 2013. Sequential Gaussian simulation in the Sungun $\mathrm{Cu}$ porphyry deposit and comparing the stationary reproduction with ordinary kriging. Universal Journal of Geoscience 1, 106-113.

Stacher, P., 1995. Present understanding of the Niger Delta hydrocarbon habitat. [In:] M.N. Oti \& G. Postma, G. (Eds): Geology of Deltas: Balkema, Rotterdam, 257-267.

Tanmay, C., 2008. Permeability estimation using flow zone indicator from well log data. $7^{\text {th }}$ International Conference and Exhibition on Petroleum Geophysics, Hyderabad, 7 pp.

Uguru, C.I., Onyeagoro, O.U., Lin, J. Okkerman, J. \& Sikiru, I.O., 2005. Permeability prediction using Genetic Unit Average of Flow Zone Indicators (FZIs) and Neural Networks. Society of Petroleum Engineers Annual Conference, Abuja, Nigeria, paper 98828, 8 pp.

Manuscript received: 8 December 2019 Revision accepted: 20 September 2020 